\title{
PASSZÍV SZOLÁRIS NYERESÉGEK VIZSGÁLATA A DEM KUTATÓSZOBÁK ENERGIAFELHASZNÁLÁSÁNAK TÜKRÉBEN
}

\section{ENERGY CONSUMPTION BASED EXAMINATION OF PASSIVE SOLAR GAINS IN THE CARRELS OF THE DEM}

\author{
Fiál Ádám \\ Debreceni Egyetem, Müszaki Kar, Épületgépészeti és Létesitménymérnöki Tanszék, \\ 4028, Debrecen, Ótemetö u. 2-4.; fialadam@gmail.com
}

\begin{abstract}
In this study we examined the heating energy consumption and the indoor temperature in function of the solar radiation in the carrels of the Sustainable Energy Research Center of University of Debrecen (DEM). After evaluation of the measurements, we developed a numerical model that describes the heat-gain caused by the solar radiation. With the constructed model we estimated the theoretical heat gain in the research room however the functions weren't fit with the results of measurement. In the rest of the study we discussed the reasons of the differences, for example the changes in the heat storage mass calculations or the real meaning of the internal temperature from the calculations.
\end{abstract}

Keywords: solar gain, heat storage mass, thermal load, direct solar system, numerical model.

\section{Összefoglalás}

A jelen tanulmányban többek között a kutatószobák fütési energiafelhasználását vizsgáltuk különböző besugárzási körülmények között, valamint az épületbe jutó napsugárzás okozta felmelegedést követtük nyomon a Debreceni Egyetem Fenntartható Épületenergetikai Információs Központjában (rövidebb nevén: Dem). A mérések kiértékelése után egy számítási modellt állítottunk fel. A modell segítségével meghatároztuk kutatószobák felmelegedését, azonban a kapott eredmények nem egyeztek meg a mért értékekkel. A dolgozat további részében ennek az eltérésnek az okait kerestük, mint például a hőtároló tömeg figyelembevételének módja, az eltérő mért és a számított hömérséklet.

Kulcsszavak: szoláris nyereség, hötároló tömeg, höterhelés, direkt szoláris rendszer, számitási modell.

\section{Mérési körülmények}

$\mathrm{Az}$ épületben három kutatószoba található az épület déli-, keleti-, és nyugati sarkában. A szobák belső környezet jellemzöit számos berendezés vizsgálja, méri és archiválja. A mérés során a 3 kutatószobában, azonos időpontban, de eltérő feltételek (szoláris nyereségek, hőtároló tömeg) mellett mértük az energiafelhasználást és a belső hőmérsékleteket.

\subsection{Mérési időszakok}

A kísérleti időszak több szakaszból állt. Elsőként egy felfütési/kalibrációs időszakra volt szükség, hogy leellenőrizhessük az archiváló rendszer pontosságát. Ezután kövezhettek a mérési szakaszok:

- az első, március 31-től, április 4-ig, mikor a keleti helyiségek összes 
árnyékolóját elhúztuk a mérési intervallum idejére;

- a második, április 8-tól, április 11-ig, amikor csak a keleti nyílászárók árnyékolóit húztuk el, és az 1-es kutatószoba belső falaira hőszigetelést helyeztünk el;

- a harmadik, április 14-től, április 19-ig, amikor csak a déli helyiségek déli árnyékolóit nyitottuk ki, és a 3-as kutatószoba falaira hőszigetelést helyeztünk el.

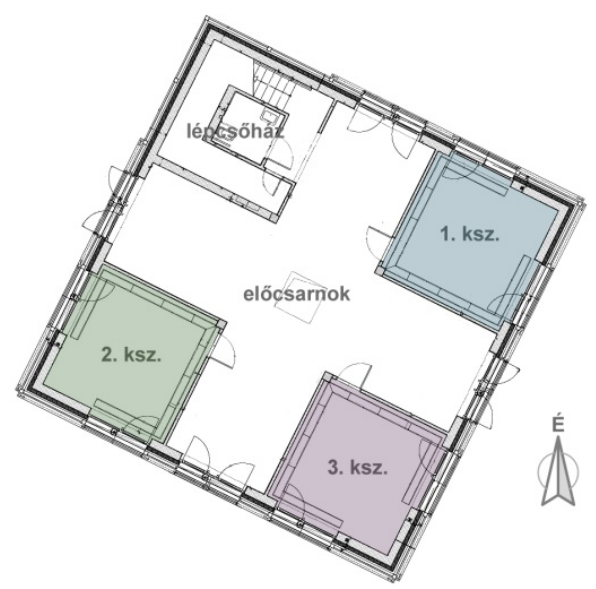

1. ábra. A Dem földszinti alaprajza

A mérési időszakban a felhőzetet fényképekkel dokumentáltuk. A mérés során archivált adatokat a későbbiekben felhasználtuk a számítási modell finomítása során.

\section{A számítási modell felállítása}

\subsection{Elméleti alapok}

Egy helyiséget tekinthetünk egy hőtároló tömeggel rendelkező egységnek, melybe a befolyó áram a szoláris energia, a kifolyó áram pedig a helyiség hőmérsékletének és a külső hőmérsékletnek a különbségével arányos hőveszteség. Ekkor a rendszer leírható egy kapacitásos késleltető, vagy más néven egytárolós arányos elemi egység dinamikus állapotfüggvényével. Kanonikus alakja [1.]:

$$
\frac{d v}{d t}=\frac{1}{C} \phi_{b}(t)-\frac{k}{C} v
$$

(1) ahol: $\mathrm{V}-\mathrm{a}$ vizsgált intenzív jellemzö, t - idő, C - kapacitástányező, $\phi_{\mathrm{b}}(\mathrm{t})$ - a bemenő áram időfüggvénye, $\mathrm{k}$ veszteségtényező. A függvény integrálva és átrendezve:

$$
v(t)=\frac{\phi_{b 1}}{k}\left(1-e^{-\frac{k}{c} t}\right)
$$

A mi esetünkben a bemenő áram az ablakon bejutó napsugárzás energiaárama, amely időben változó, hiszen reggel mikor felkel a nap nem olyan szögben, és nem akkora intenzitással éri az üvegfelületeket a napsugárzás, mint mondjuk délben.

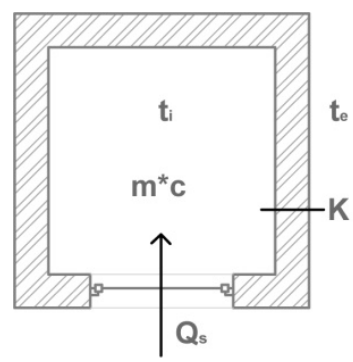

\section{2. ábra. Ideális számítási szobamodell}

A belső léghőmérséklet ti $\left[{ }^{\circ} \mathrm{C}\right]$, a külső hömérséklet te $\left[{ }^{\circ} \mathrm{C}\right]$, amit jelen esetben állandónak tekintünk. Az épületben a belső hőtároló kapacitása: $\mathrm{m}^{*} \mathrm{c} \quad[\mathrm{kJ} / \mathrm{K}]$, ebbe beletartozik a falak belső oldala a hatályos elöírások szerinti vastagságig. Az elemi helyiség veszteségtényezője: $\mathrm{K} \quad[\mathrm{kJ} / \mathrm{K}]$, amely a helyiséget határoló épületszerkezetek hőátbocsátási tényezőiből és azok felületéből, a helyiség térfogatból és a légcsereszámból számítható. A helyiségbe beérkező hőteljesítmény értéke: Qs, a bemeneti jel. A rendszertechnikai 
képletbe behelyettesítve a helyiségre vonatkozó elemeket, a következő összefüggést kapjuk:

$$
\varphi_{i 1}=\frac{Q_{s d 1}}{K}\left(1-e^{-\frac{K}{m c} \tau}\right)+\varphi_{i 0} e^{-\frac{K}{m c} \tau}
$$

Amennyiben az időben változó Qs bemenő jelet impulzusokkal közelítjük, az összefüggés segítségével kiszámíthatjuk az időben változó napsugárzás okozta felmelegedés mértékét a belső térben, emellett tartalmazza az előző vizsgált időperiódusban leadott energia válaszreakciójának pillanatnyi állását is, azaz a $\varphi_{\mathrm{i} 0}$ tényezöt.

\section{Számítási eredmények}

A mért értékeket és a számítási metódusokat Microsoft Excel programban helyettesítettem be. Az egyszerüség kedvéért az első három napot vizsgáltam az első mérési szakaszon belül, mert akkor teljesen tiszta volt az ég és nem kell kellett számolnom a felhözet sugárzást csökkentő hatásával. Azonban a számításból kapott eredmények és a mért értékek nem fedték egymást. Az eltéréseknek számos oka lehet, pl. mérési pontatlanság, számítási hibák stb. Viszont az ellenőrzések során kiderült, hogy az eddigi számításaink, méréseink és felvetéseink pontosak voltak.

\section{A számítási módszert javító metódusok}

\subsection{A hőtároló tömeg csökkentése}

Direkt szoláris rendszeres rendszerek esetében meg kell különböztetnünk különböző fontosságú hőtároló tömegeket. Elsődleges hőtároló tömegek azok a belső épületszerkezetek, melyeket közvetlenül ér az üvegezésen bejutó direkt napsugárzás. Szokványos esetben ez a padló, leginkább itt van szükség jó elnyelö-képességü és nehéz szerkezetekre, burkolatokra.

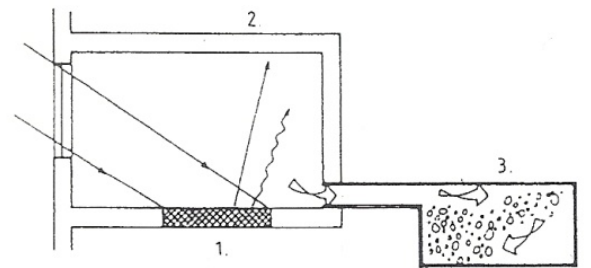

Az elsődleges (1), másodlagos (2) és „kihelyezett” hőtároló tömegek értelmezéséhez

3. ábra. A hötároló tömegek fontossága a direkt szoláris rendszerekben (forrás:[2.])

\subsection{A számításból kapott eredmények újraértelmezése}

A napfény a belső levegöt úgy melegíti fel, hogy a bejutó sugarakat elnyelő szerkezet felmelegedik, és aztán konvekció útján leadja a levegönek az energiája egy részét. Mivel a levegő hőtároló tömege elhanyagolható, hőmérséklete csak néhány perces késéssel követi a belső burkolófelületek.

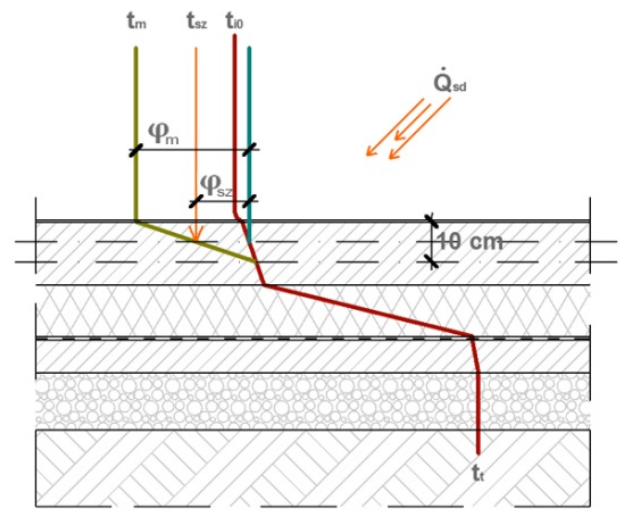

4. ábra. A höátadás szemléltetése

A 4. ábrán piros vonallal jelöltem a padlószerkezet hőmérsékleteloszlását általános esetben, azaz a kezdeti állapotban, amikor még nem éri napsugárzás a padlót. $\mathrm{t}_{\mathrm{i} 0}$-al jelöltem a kezdeti belső hőmérsékletet, $\mathrm{t}_{\mathrm{t}}$-vel pedig a talaj hőmérsékletét. Ebben a pillanatban a belső hőtároló tömeg, vagyis a 
sematikus ábrán bemutatott esetben a felső 10 cm-es réteg középpontjában mérhetö hőmérséklet a narancssárga vonallal jelzett érték. Ez természetesen csak akkor helyes, ha a hötároló tömegben a hőmérsékleteloszlást lineárisan közelítjük. Ez azaz érték, amelyet a számítási modellben kiszámítunk, viszont a mért belső léghőmérséklet nem egyezik meg ezzel, hiszen a felület melegebb, mint a hőtároló tömeg átlagos hőmérséklete.

\subsection{A számítást módosító egyéb tényezők}

A mért és számított értékek közötti eltérést okozhatja a helyiség hőátbocsátási tényezőjének a valós éréke, a sugárzási értékek kiszámításánál figyelembe nem vett tényezők, mint az aktuális felhőzet besugárzott energiát redukáló hatásának figyelembevétele, vagy a beépített környezet időbeli változása, a kutatószobák közötti közös használatú tér eltérö hőmérséklete.

\section{Eredmények}

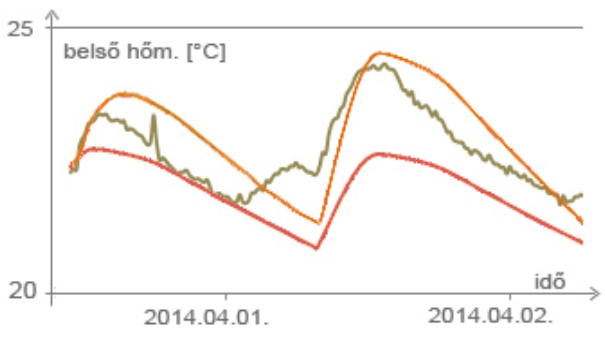

5. ábra. Számitási eredmények

A számítási metódus kalibrálásával a mért belső léghőmérséklet és a számított érték már jobban fedik egymást, mint az az 5. ábrán is jól látható. Zöld színnel jelzem a mért léghőmérsékletet, pirossal a kalibrálás előtti számítási eredményt, valamint narancssárgával a módosított számításból kapott eredményeket. Az energiafelhasználásból is vontunk le következtetéseket:

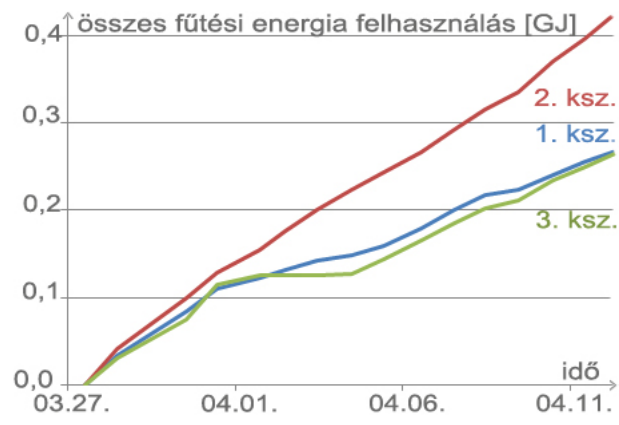

6. ábra. Fütési energiafelhasználás

A 6. ábrán látható a fütési energiafelhasználás a teljes kutatási időszak egy részében. Jól látszik, hogy az 1-es és 3as kutatószobában sokkal kevesebb (kétharmada) volt a fütési energiafelhasználás annak ellenére, hogy csak kilenc napot volt elhúzva a nyílászárót árnyékoló panel az egész kutatási időszak alatt.

\section{Következtetések}

A felmelegedés pontos kiszámításának metódusa a rengeteg változó körülmény és be nem számolt módosító tényezők miatt további munkára szorul. Szükségesnek ítélnék még a továbbiakban, egy a padló hőtároló tömegének kizárására folyó kísérletet, melyben a padlófütési rendszert is kiváltanánk egy másik, akár elektromos hősugárzós berendezéssel, hogy megállapíthassuk az elsődleges hőtároló tömegek valós számszeri jelentőségét. Ezen kívül érdemes lenne megvizsgálni a hőtároló tömegek pontos rétegenkénti felmelegedését is a Napból érkező sugarak hatására.

\section{Szakirodalmi hivatkozások}

[1.] Dr. Szabó Imre: Gépészeti rendszertechnika, Müszaki könyvkiadó, Budapest, 1986.

[2.] Prof. Zöld András: Energiatudatos épitészet, Müszaki könyvkiadó, Budapest, 1999. 